\title{
INFLUENCE OF NANOPARTICLES INTRODUCING IN THE MELT OF ALUMINUM ALLOYS ON CASTINGS MICROSTRUCTURE AND PROPERTIES
}

\author{
R. Lazarova, N. Bojanova, R. Dimitrova, and V. Manolov \\ Institute of Metal Science, Equipment and Technologies "Acad. A.Balevski” with Hydro Aerodynamics Centre - BAS, 67 \\ Shipchenski prohod Blvd, 1574 Sofia, Bulgaria
}

I. Panov

Branch of TU - Sofia in Plovdiv, 25 Tz. Dyustabanov St, 4000 Plovdiv, Bulgaria

Copyright $@ 2016$ The Author(s). This article is published with open access at Springerlink.com

DOI 10.1007/s40962-016-0033-7

\begin{abstract}
Three types of aluminum alloys such as AlSi7Mg, AlSi12Cu2MgNi and AlZn4 are refined by introducing nanoparticles of high melting temperature compoundsnitrides and carbides as well as diamonds in the melt. Their influence on microstructure, mechanical and some electrochemical properties of castings of these alloys is investigated. It is established that the microstructure is refined, the porosity is decreased, and some mechanical
\end{abstract}

Abstract

and electrochemical properties such as protection potential in drinking water are increased. The mechanism of grain refinement and silicon modification is discussed.

Keywords: nanoparticles, casting, aluminum alloys, refining, mechanical and electrical properties

\section{Introduction}

Nanosized particles (NP) are used as inoculants for refining the metal microstructure and improving the mechanical properties of products in the last years. ${ }^{1-5}$ Powders of high melting temperature $\left(2000-3000{ }^{\circ} \mathrm{C}\right)$ compounds, nitrides, carbides, borides, etc. with nanodimensions, are introduced in the molten metal. They are obtained usually by means of plasma chemical synthesis and are covered with metal protector. When a homogenous introduction of nanopowders is reached, a local overcooling and volume crystallization conditions are created and the nanoparticles become active centers of crystallization. The investigations of refined with nanoparticles metal alloys show that the mechanical properties (tensile strength and specific elongation $^{1-5}$ ) as well as the corrosion and abrasive resistance ${ }^{6}$ increase. Nanoparticles increase the part of the surface energy in the total energetical balance of an alloy which determines the phase transformations. Most of the nanoparticles have low wettability, and so it is difficult to

Dedicated to his Eminence Photius-Bishop of Triaditsa on the Occasion of His 60th Birthday. be wet by the melts. For this reason, they are clad with metal protector. Most of the existing studies are performed on $\mathrm{Al}$ alloys, ${ }^{1,5,7-10} \mathrm{Mg}$ alloys, ${ }^{11,12}$ cast iron ${ }^{4-6,13}$ and some on steels with specific application. ${ }^{3-5}$ This work enriches the investigations on castings of three types of aluminum alloys refined with nanoparticles.

Aim: The aim of the present work was to investigate the influence of some types of nanoparticles on the structure and properties of aluminum alloys castings.

\section{Experimental}

\section{Production of Nanopowders}

High melting temperature compounds in form of nanopowders are obtained by plasma chemical synthesis. Nanopowders of TiCN, SiC, TiN and AlN are produced by Neomat CO, Latvija and the Institute of Theoretical and Applied Mechanics-Siberian Branch of RAS. They are passivated with oleic acid for atmospheric influence protection. In order to reach better wettability, the 
nanoparticles are clad with metal protector $(\mathrm{Ni}, \mathrm{Cr}, \mathrm{Fe}, \mathrm{Al}$, $\mathrm{Cu}$, etc.). This is realized by mechanical and chemical processing in planetary mills or free-current method. ${ }^{14}$

For refining, aluminum alloys could be used also diamond nanopowders (ND). They are obtained by detonation technology and are clad with metal protector using freecurrent method.

$\mathrm{NP}$ of $\mathrm{SiC}$ clad with $\mathrm{Cu}$ by free-current method is shown in Figure 1. The presence of larger particles with diameter up to $600 \mathrm{~nm}$ as well as smaller ones with diameter up to $100 \mathrm{~nm}$ is observed.

\section{Investigated Alloys Castings}

Three aluminum alloys castings are investigated, namely "Boat" of AlSi7Mg alloy, piston of AlSi12Cu2MgNi alloy and anode, protector of AlZn4 alloy, as given in Table 1.

$\mathrm{AlSi} 7 \mathrm{Mg}$ is refined with:

- $\quad 0.05 \% \mathrm{AlN}$ and cladding metals $\mathrm{Al}+\mathrm{Cu}$

- $0.1 \% \mathrm{SiC}$ and cladding metal $\mathrm{Cu}$

$\mathrm{AlSi} 12 \mathrm{Cu} 2 \mathrm{MgNi}$ is refined with:

- $\quad 0.1 \% \mathrm{ND}+\mathrm{Ag}$

- $0.1 \% \mathrm{SiC}+\mathrm{Cu}$

- $\quad 0.1 \% \mathrm{SiC}+\mathrm{Cu}+0.03 \% \mathrm{AlN}+\mathrm{Al}$ [ultrasonic dispersion (USD)]

$\mathrm{AlZn} 4$ is refined with:

- $0.05 \% \mathrm{AlN}+\mathrm{Al}(\mathrm{USD})$

- $0.1 \% \mathrm{ND}+\mathrm{Ag}$.

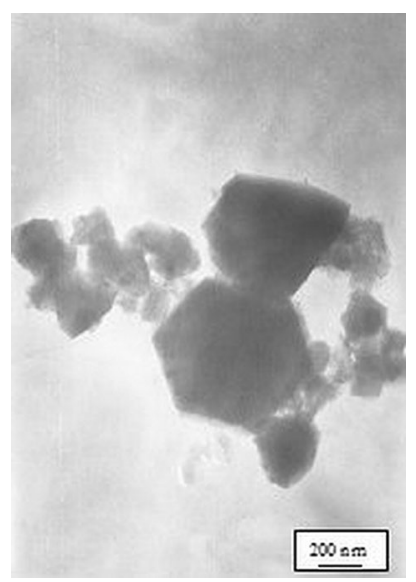

Figure 1. SiC particles cladded with $\mathrm{Cu}$.
Technology of Nanoparticles Addition and Casting with and Without Nanoparticles

The technology of NP introduction and casting "Boat" of AlSi7Mg alloy consists in:

- Melting the Al alloy in electric-resistance furnace with crucible capacity of $2.5 \mathrm{~kg}$;

- Degassing molten metal at $730-740{ }^{\circ} \mathrm{C}$ by means of blow-through with argon through graphite tube with flow $1 \mathrm{l} / \mathrm{min}$ for $5 \mathrm{~min}$;

- Introducing NP wrapped in aluminum foil and capsulated in aluminum cartridge in the melt at $720-740{ }^{\circ} \mathrm{C}$ and mechanical stirring with Timixer for 3-5 min (rotational speed-up to $150 \mathrm{~min}^{-1}$ );

- Casting in metal mold.

Castings for pistons with $45 \mathrm{~mm}$ diameter and $0.17 \mathrm{~kg}$ weight of $\mathrm{AlSi} 12 \mathrm{Cu} 2 \mathrm{MgNi}$ alloy are produced by direct squeeze casting. This method assures high crystallization rate which means fine microstructure. The castings are designed for pistons with diameter $38-40 \mathrm{~mm}$ for racing motorcycles and carting engines with $50 \mathrm{~cm}^{3}$ volume, air cooling and velocity up to $12,000 \mathrm{rpm}$.

The castings with and without NP are produced in the following conditions:

- Melting the Al alloy in furnace with capacity of $6 \mathrm{~kg}$;

- Temperature of the melt in the furnace 730-740 ${ }^{\circ} \mathrm{C}$;

- Molten metal degassing by means of blowthrough with argon through graphite tube for 3-5 min;

- Temperature of the mold and the punch $150-160{ }^{\circ} \mathrm{C}$;

- Pressing pressure during crystallization$188 \mathrm{MPa}$;

- Time from the end of pouring up to applying pressure 3-4 s;

- $\quad$ Time of applying pressure $20 \mathrm{~s}$.

The technology of introducing NP and casting anodeprotector of AlZn4 alloy-consists in:

- Obtaining AlZn4 alloy in electric-resistance furnace with crucible capacity of $2.5 \mathrm{~kg}$;

- Melt degassing at $730-740{ }^{\circ} \mathrm{C}$ by means of blowthrough with argon through graphite tube for 3-6 min;

- Introducing NP, wrapped in aluminum foil and capsulated in aluminum cartridge in the melt at $740-750{ }^{\circ} \mathrm{C}$ and mechanical stirring melt with $\mathrm{Ti}$ mixer for 3-5 min (rotational speed-up to $150 \mathrm{~min}^{-1}$ ); 
Table 1. Chemical Composition of Investigated Alloys, wt\% (Al-the Rest)

\begin{tabular}{|c|c|c|c|c|c|c|c|c|c|c|c|c|}
\hline Alloy & $\mathrm{Si}$ & $\mathrm{Mg}$ & $\mathrm{Ti}$ & $\mathrm{Fe}$ & $\mathrm{Cu}$ & $\mathrm{Mn}$ & $\mathrm{Zn}$ & $\mathrm{Pb}$ & Sn & $\mathrm{Ni}$ & $\mathrm{Cd}$ & $\ln$ \\
\hline AISi7Mg & 7.73 & 0.34 & 0.02 & 0.53 & 0.05 & 0.03 & 0.10 & 0.08 & 0.05 & - & - & - \\
\hline AISi12Cu2MgNi & 12.73 & 0.87 & 0.10 & 0.39 & 3.30 & 0.12 & 0.10 & 0.003 & 0.003 & 1.75 & - & - \\
\hline AlZn4 & 0.08 & - & - & 0.18 & 0.05 & - & 3.00 & - & 0.10 & - & 0.1 & 0.03 \\
\hline
\end{tabular}

- The as-obtained alloy is cast according to ${ }^{15}$ in biseat metal mold at melt temperature $720-725{ }^{\circ} \mathrm{C}$ and mold temperature $150-160{ }^{\circ} \mathrm{C}$.

\section{Investigation of Microstructures, Mechanical and Electrochemical Characteristics of Samples from Castings}

Metallographic samples are prepared by standard procedure consisting in wet grinding and mechanical polishing. The microstructure of AlSi7Mg and $\mathrm{AlSi} 12 \mathrm{Cu} 2 \mathrm{MgNi}$ samples is revealed with $0.5 \%$ water solution of $\mathrm{HF}$. The microstructure of $\mathrm{AlZn} 4$ samples is revealed by means of electrolytic etching. The microstructure is characterized by means of metallographic microscope PolyvarMet at magnifications up to $1000 \times$. The quantitative metallographic analysis is carried out by automatic image analyzing system "Olympus MicroImage." The dendrite arm spacing (DAS), domain and grain size are determined. Si crystals size control is performed. The microhardness of specimens is measured by means of the device MicroDuromat 4000 with load of $10 \mathrm{~g}$, time for reaching the load $10 \mathrm{~s}$ and hold time $10 \mathrm{~s}$.

The mechanical properties are determined by standard procedure.

The density $d$ of the melts is measured using gravimetric method. The theoretical density $\left(d_{0}=2.7050 \mathrm{~g} / \mathrm{cm}^{3}\right)$ of the melts is calculated via additive approach based on the densities and concentrations of components. The porosity $P$ $(\%)$ is defined through the formula:

$P=\frac{d_{0}-d_{\text {mean }}}{d_{0}} 100 \%$

The installation for obtaining polarization curves and thus estimating electrochemical properties is shown in Figure 2. The polarization curves present the dependence of potential on density of polarization current $[E=f(i)]$.

The anode polarization potential is determined at a current density of $5 \mathrm{~A} / \mathrm{m}^{2}$

The investigations held at current density $5 \mathrm{~A} / \mathrm{m}^{2}$ gave a possibility to determine the anode current density at which starts and ends the fast polarization. As-received experimental data showed that at anode current density $i_{\mathrm{a}}=0.01 \mathrm{~mA} / \mathrm{cm}^{2}$ fast anode polarization starts. Based on

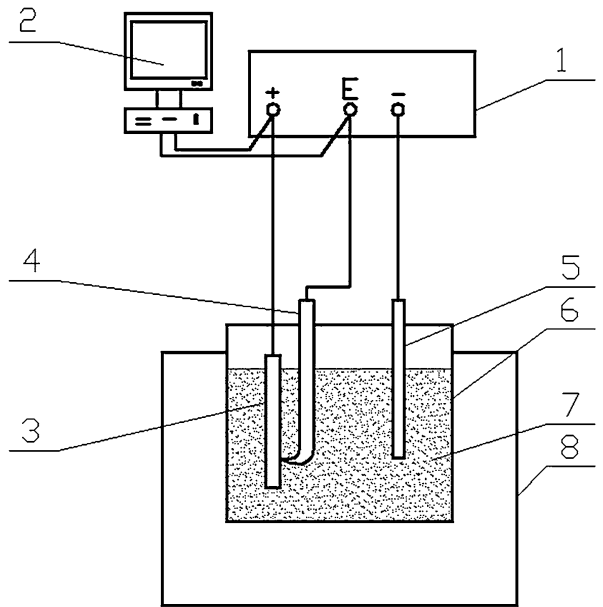

Figure 2. Installation for obtaining polarization curves. 1-Potentiostat 263A-1; 2-PC; 3-tested electrode; 4comparative electrode ( $\mathrm{Ag} / \mathrm{AgCl})$; 5-control electrode (Pt); 6-analytical cell; 7-electrolyte (drinking water); and 8-circulation thermostat UNIC-200.

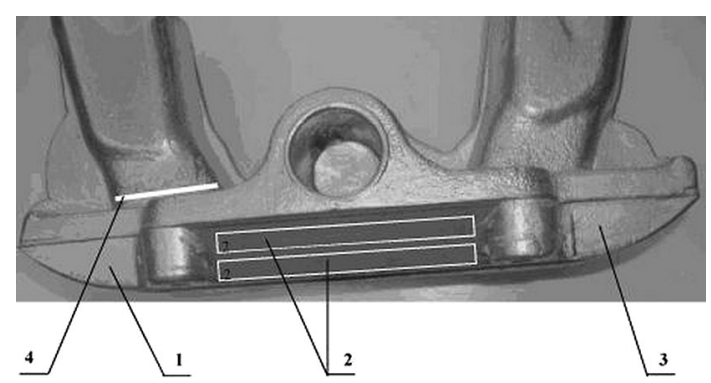

Figure 3. Casting "Boat"-detail of a power-transmission network and zones of casting samples: zone 1from the side of the riser with cross section $6.6 \mathrm{~cm}^{2}$ (for testing density and metallographic sample); zone 2with cross section $12.1 \mathrm{~cm}^{2}$ (for testing density and mechanical properties); zone 3-from the side of the runner (gate) with cross section $6.6 \mathrm{~cm}^{2}$ (for testing density); and zone 4-section of the riser (for testing density and sample for macro-analysis).

these data, we chose as an anode current density $i_{\mathrm{a}}=12 \mu \mathrm{A} / \mathrm{cm}^{2}$. The testing temperatures are 20, 30, 40, $50,60,70,80$ and $90^{\circ} \mathrm{C}$.

After measuring the potential at a given temperature, the next higher temperature is set using a thermostat. The time 
for reaching needed temperature is from 12 to $15 \mathrm{~min}$. To make sure that the temperature in the thermostat and the voltaic cell is equalized as well as to reach the equilibrium potential, it is put on hold for another 45 min-i.e., the measured potential is per hour. The thermostat and galvanic cell temperature control is held via tarred and tested immersion thermocouple with precision of $0.5^{\circ} \mathrm{C}$.

The potential of anode alloys at a given current density which is equal or higher than the one taken for a minimum borderline potential $\left(E_{\min }=-980 \mathrm{mV}\right)$ could be used as protectors. It shall be noticed that according to international standards, the minimum necessary protective potential for low-alloyed steels is as follows: $E=-720$ to $760 \mathrm{mV}$ at $20^{\circ} \mathrm{C}$ and $E=-920 \mathrm{mV}$ at $85^{\circ} \mathrm{C}$.
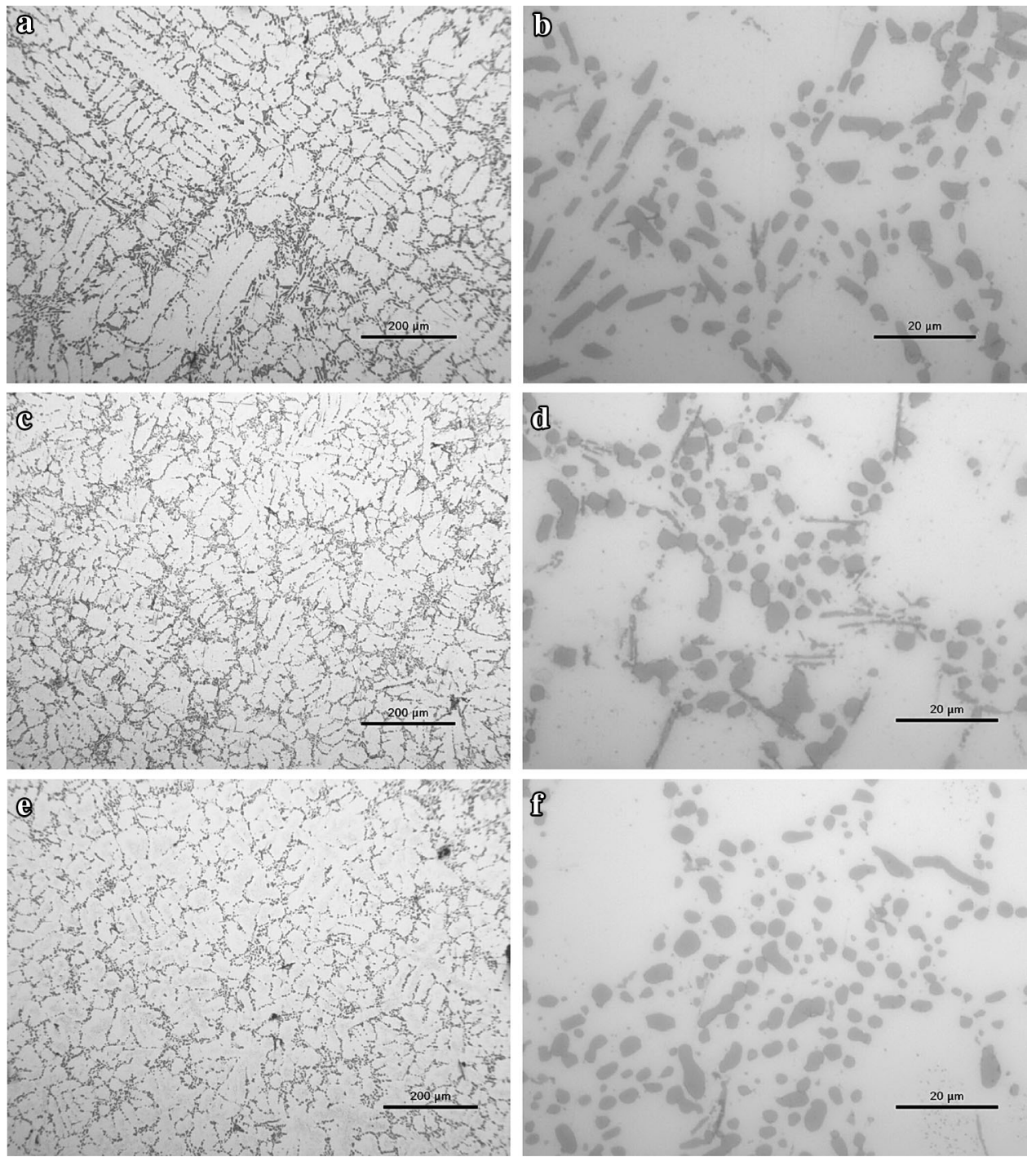

Figure 4. Microstructures of castings type "Boat" of AISi7Mg after HT: (a, b) casting 1 without NP; (c, d) casting 2 refined with $0.05 \% A I N+A I+C u ;(e, f)$ casting 3 refined with $0.1 \% \mathrm{SiC}+\mathrm{Cu}$; $(\mathrm{a}, \mathrm{c}, \mathrm{e})$ general view of the microstructure; and $(b, d, f)$ eutectic. 
Table 2. Microstructure, Physical and Mechanical Characteristics of Refined and Unrefined Castings "Boat" (Alloy AlSiTMg) After HT (Regime T6)

\begin{tabular}{llcccccccc}
\hline $\begin{array}{l}\text { Casting } \\
\text { no. }\end{array}$ & $\begin{array}{l}\text { Type and } \\
\text { concentration of NM }\end{array}$ & $\begin{array}{l}\text { DAS } \\
(\mu \mathrm{m})\end{array}$ & $\begin{array}{l}\text { Length of } \mathrm{Si} \\
\text { particles }(\mu \mathrm{m})\end{array}$ & $\begin{array}{l}R_{0.2} \\
(\mathrm{MPa})\end{array}$ & $\begin{array}{l}R_{m} \\
(\mathrm{MPa})\end{array}$ & $\begin{array}{l}A_{5} \\
(\%)\end{array}$ & $Q(\mathrm{MPa})$ & $\begin{array}{l}d\left(\mathrm{~g} / \mathrm{cm}^{3},\right. \\
\text { zone II) }\end{array}$ & $\begin{array}{l}P(\%, \\
\text { zone II) }\end{array}$ \\
\hline 1 & Without NP & 23.90 & 3.52 & 240 & 296 & 4.0 & 386 & 2.6783 & 0.99 \\
2 & $0.05 \%$ & 17.69 & 2.94 & 253 & 318 & 4.3 & 413 & 2.6956 & 0.35 \\
& AlN + Al + Cu & & & & & & & & \\
& Alteration (\%) & -26.0 & -16.5 & 5.4 & 7.4 & 7.5 & 7.0 & 0.70 & -64.6 \\
3 & 0.1 \% SiC + Cu & 17.66 & 2.59 & 238 & 317 & 6.4 & 438 & 2.6950 & 0.37 \\
& Alteration (\%) & -26.0 & -26.4 & -0.8 & 7.1 & 60.0 & 13.5 & 0.62 & -62.6 \\
\hline
\end{tabular}

- $\quad$ aging at $160 \pm 3{ }^{\circ} \mathrm{C}-6 \mathrm{~h}$.

The microstructures are shown in Figure 4. They present dendrites of $\alpha$-solid solution and eutectic of $\alpha$-solid solution, $\mathrm{Si}$ particles and intermetallic compounds. The microstructure, physical and mechanical characteristics of initial and refined castings "Boat" after HT (regime T6) are given in Table 2. It could be seen that the nanoparticles introducing in the melt lead to microstructure refinement. Both modifiers reduce DAS values with $26 \%$. The length of Si particles is decreased with $16.5 \%$ by AlN modifier and $26.4 \%$ by $\mathrm{SiC}$ comparing with $\mathrm{Si}$ particles length of non-modified sample. It could be supposed that the refining effect of used in this case nanoparticles is based on their properties after the metal covering is melted in the molten metal. They have (1) high melting temperature, (2) low reactivity and (3) extremely high sedimentation stability because of their small size and specific surface. ${ }^{16}$ The energy of Brownian motion is sufficient to ensure the particles with size up to 1 micron to be in permanent movement and not to be settled under gravity. ${ }^{17}$ Thereby, the nanoparticles act as nucleation centers. According to the known and generally recognized principle of orientation and size matching formulated by Dankov, ${ }^{18}$ the crystalline lattice of the new phase is oriented relative to the initial phase so that the arrangement of atoms between lattices in both phases achieves maximum similarity and that the lattice atoms underwent minimal displacement. The crystal structure of $\operatorname{SiC}$ ( $\beta$, which is used by us) is cubic with lattice parameter $a=4.3596 \AA$. The $\mathrm{Al}$ one is also cubic with $a=4.046 \AA$. The difference between lattice constants is $7.19 \%<10 \%$, so the requirement for orientation and size matching is fulfilled and the $\mathrm{SiC}$ particles could be substrate on which the $\mathrm{Al}$ crystals generate. It could be assumed that this requirement is not obligatory for nanomodifiers since the AlN does not fulfill it, but the microstructure is refined. Such a finding is made in Stanev et al. ${ }^{19}$ where diamond nanopowder is used as modifier for AlSi7Mg, and although its crystalline constant differs with $12 \%$ from $\mathrm{Al}$ one, the grains are refined. Proving or disproving this assumption requires further research on crystal lattice level. We suppose the $\mathrm{Si}$ particles are refined and rounded because of diminished volumes between dendrite arms (DAS) where the particles grow. Nanoparticles have a double-modifying effect: firstly, they serve as centers of crystallization, and secondly, being very numerous in number and being a long time in a suspended state, they block the diffusion of the respective atoms to emerging and growing crystals that in the end contributes to a finegrained structure formation. ${ }^{17,20}$ It is found that irrespective of the chemical composition of the NP, their crystal system, crystal lattice constants, density, melting temperature and other parameters, they all have similar modifying effect. $^{20}$

As a result of NP introducing in the melt of AlSi7Mg, microstructure refinement is obtained and mechanical properties are improved. In the case of AlN using as modifier, the mechanical characteristics are raised with several percent, as given in Table 2. The elongation increases mostly with $60 \%$. That is due especially to the $\mathrm{Si}$ particles length reduction with $26.4 \%$.

The influence of NP on porosity and quality index Q of casting "Boat" is presented in Figure 5. The quality index $Q$ is calculated by the formula: ${ }^{21}$

$Q=R_{m}+150 \log A_{5}(\mathrm{MPa})$

It is noted that both modifiers reduce the porosity significantly from about 1 to $0.4 \%$. The presence of a sufficient quantity of nanoparticles leads to the emergence of smaller crystals and thus assures greater density of the casting.

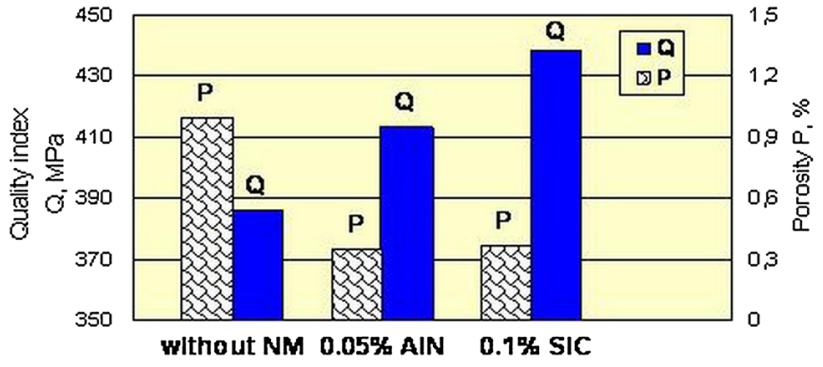

Figure 5. Influence of NP on the porosity and quality index $Q$ of casting "Boat." 

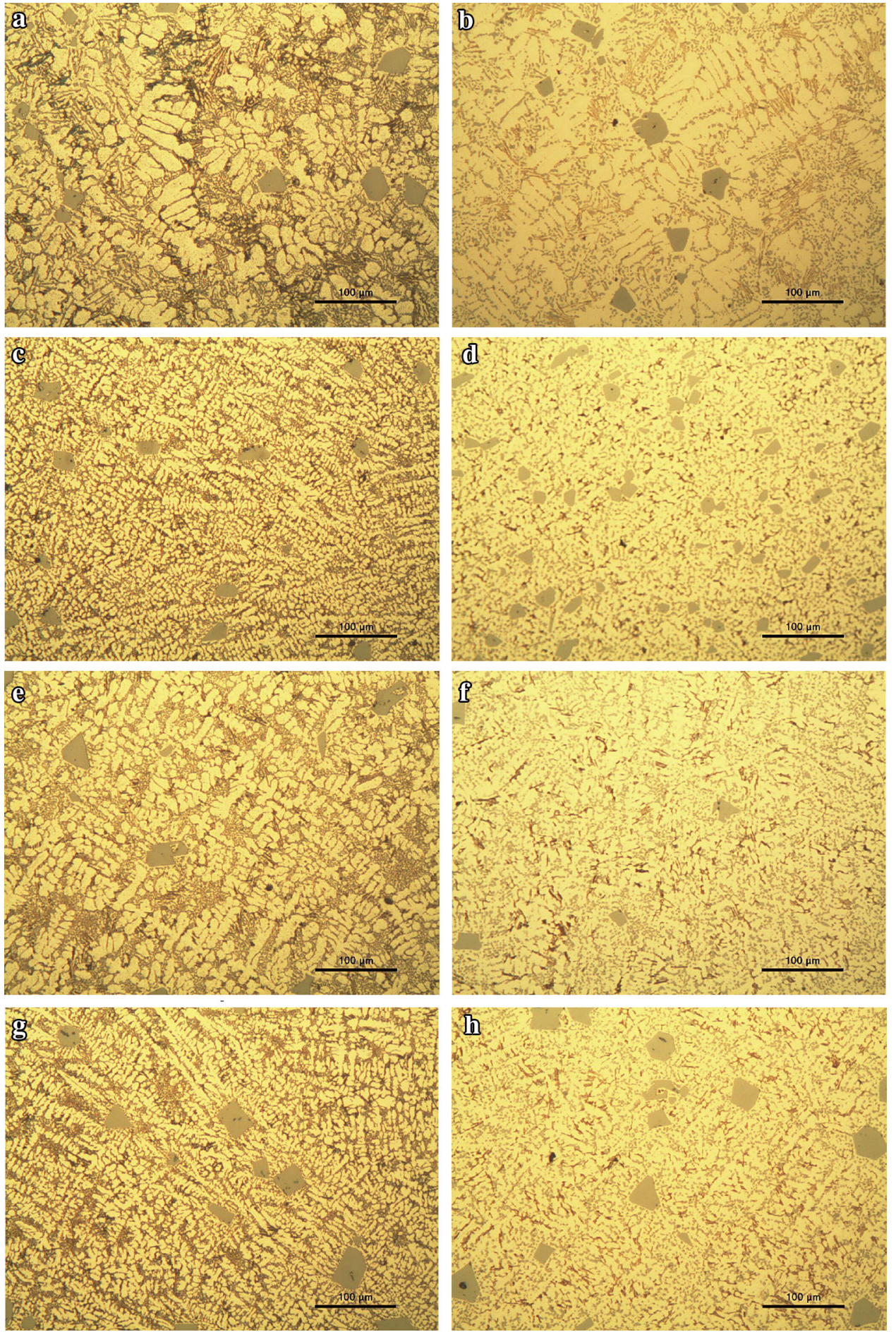

Figure 6. Microstructure of AISi12Cu2MgNi alloy: (a, c,e, g) in as-cast stay and (b, $d, f, h)$ after heat treatment. (a, b) Samples without NP; (c, d) samples with $0.1 \%$ $\mathrm{ND}+\mathrm{Ag}$; (e, f) samples with $0.1 \% \mathrm{SiC}+\mathrm{Cu}$; and $(\mathrm{g}, \mathrm{h})$ samples with $0.1 \%$ $\mathrm{SiC}+\mathrm{Cu}+0.03 \% \mathrm{AIN}+\mathrm{Al}$. 
Table 3. Testing Results of Pistons Before and After HT

\begin{tabular}{|c|c|c|c|c|c|c|}
\hline Type and concentration of NP & $\mathrm{DAS}(\mu \mathrm{m})$ & $d \mathrm{cp}^{\mathrm{a}}\left(\mathrm{g} / \mathrm{cm}^{3}\right)$ & $R_{0.2}^{\mathrm{a}}(\mathrm{MPa})$ & $R_{m}^{\mathrm{a}}(\mathrm{MPa})$ & $A_{5}^{\mathrm{a}}(\%)$ & $\mathrm{HB}^{\mathrm{a}}$ \\
\hline Without NM & 10.56 & $2.7685 / 2.7689$ & $243 / 367$ & $266 / 388$ & $0.4 / 0.5$ & $114 / 154$ \\
\hline $0.1 \% \mathrm{ND}+\mathrm{Ag}$ & 8.67 & $2.7686 / 2.7692$ & $233 / 369$ & $273 / 393$ & $0.7 / 0.6$ & $118 / 154$ \\
\hline Alteration (\%) & -17.9 & - & $-4.1 / 0.5$ & $2.6 / 1.3$ & $75 / 20$ & $3.5 / 0$ \\
\hline $0.1 \% \mathrm{SiC}+\mathrm{Cu}$ & 9.64 & $2.7694 / 2.7696$ & $238 / 373$ & $283 / 402$ & $0.7 / 0.7$ & $117 / 154$ \\
\hline Alteration, \% & -8.7 & - & $-2.1 / 1.6$ & $6.4 / 3.6$ & $75 / 40$ & $2.6 / 0$ \\
\hline $0.1 \% \mathrm{SiC}+\mathrm{Cu}+0.03 \% \mathrm{AIN}+\mathrm{Al}$ (USD) & 7.92 & $2.7698 / 2.7700$ & $245 / 371$ & $281 / 404$ & $0.7 / 0.8$ & $115 / 152$ \\
\hline Alteration (\%) & -25.0 & - & $0.8 / 1.1$ & $5.6 / 4.1$ & $75 / 60$ & $0.9 /-1.3$ \\
\hline
\end{tabular}

Table 4. Potential-E in Drinking Water After 1-h Stabilization

Potential-E $(\mathrm{mV})$ in drinking water after 1-h stabilization

\begin{tabular}{|c|c|c|c|c|c|c|c|}
\hline \multicolumn{2}{|c|}{$\mathrm{Nr} 1$-without NM } & \multicolumn{3}{|c|}{$\mathrm{Nr} 2.1$-with $0.05 \%$ AIN + Al (USD) } & \multicolumn{3}{|c|}{$\mathrm{Nr} 3.2$-with $0.1 \% \mathrm{ND}+\mathrm{Ag}$} \\
\hline$T\left({ }^{\circ} \mathrm{C}\right)$ & $-E(\mathrm{mV})$ & $T\left({ }^{\circ} \mathrm{C}\right)$ & $-E(\mathrm{mV})$ & $\Delta E(\%)$ & $T\left({ }^{\circ} \mathrm{C}\right)$ & $-E(\mathrm{mV})$ & $\Delta E(\%)$ \\
\hline 20 & 689 & 20 & 751 & 9.0 & 20 & 725 & 5.2 \\
\hline 30 & 744 & 30 & 780 & 4.8 & 30 & 754 & 1.3 \\
\hline 40 & 770 & 40 & 795 & 3.2 & 40 & 785 & 3.2 \\
\hline 50 & 794 & 50 & 845 & 6.4 & 50 & 834 & 5.0 \\
\hline 60 & 891 & 60 & 913 & 2.5 & 60 & 913 & 2.5 \\
\hline 70 & 1005 & 70 & 995 & -1.0 & 70 & 998 & -0.7 \\
\hline 80 & 1039 & 80 & 1023 & -1.5 & 80 & 1027 & -1.1 \\
\hline 85 & 1049 & 85 & 1031 & -1.7 & 85 & 1045 & -0.4 \\
\hline
\end{tabular}

Table 5. Potential-E (mV) in Drinking Water After 10-h Testing

\begin{tabular}{|c|c|c|c|c|c|c|c|c|c|}
\hline \multirow[t]{2}{*}{ No. } & \multirow[t]{2}{*}{ Treatment } & \multicolumn{8}{|c|}{ Temperature of drinking water $\left({ }^{\circ} \mathrm{C}\right)$} \\
\hline & & 20 & 30 & 40 & 50 & 60 & 70 & 80 & 90 \\
\hline 1 & Without NP & 1167 & 1175 & 1179 & 1202 & 1219 & 1230 & 1235 & 1253 \\
\hline \multirow[t]{2}{*}{2.1} & $0.05 \% \mathrm{AIN}+\mathrm{Al}$ (USD) & 1175 & 1181 & 1193 & 1213 & 1236 & 1244 & 1255 & 1266 \\
\hline & $\Delta E(\%)$ & 0.7 & 0.5 & 1.2 & 0.9 & 1.4 & 1.1 & 1.6 & 1.0 \\
\hline \multirow[t]{2}{*}{3.2} & $0.1 \% \mathrm{ND}+\mathrm{Ag}$ & 1173 & 1181 & 1192 & 1210 & 1233 & 1241 & 1254 & 1263 \\
\hline & $\Delta E(\%)$ & 0.5 & 0.5 & 1.1 & 0.7 & 1.4 & 0.9 & 1.5 & 0.8 \\
\hline
\end{tabular}

Table 6. Microstructure Characteristics and Density of AlZn4 Castings Designed for Protectors

\begin{tabular}{llcccc}
\hline $\begin{array}{l}\text { Casting } \\
\text { no. }\end{array}$ & $\begin{array}{l}\text { Type and concentration } \\
\text { of NM }\end{array}$ & $\begin{array}{l}\text { Mean diameter of domains } \\
d(\mathrm{~mm})\end{array}$ & $\begin{array}{l}\text { Mean grain diameter } \\
(\mu \mathrm{m})\end{array}$ & $\begin{array}{l}\text { Grain } \\
\text { roundness }\end{array}$ & $\begin{array}{l}\mathrm{HV}(\mathrm{kg} / \\
\left.\mathrm{mm}^{2}\right)\end{array}$ \\
\hline 1 & Without NP & 1.96 & 61.18 & 1.42 & 38.5 \\
$\left.\mathrm{~cm}^{3}\right)$
\end{tabular}

The electrochemical characteristics in drinking water after 1-h stabilization and after 10-h testing are shown in Table 4, Table 5 and Figure 7 , respectively 


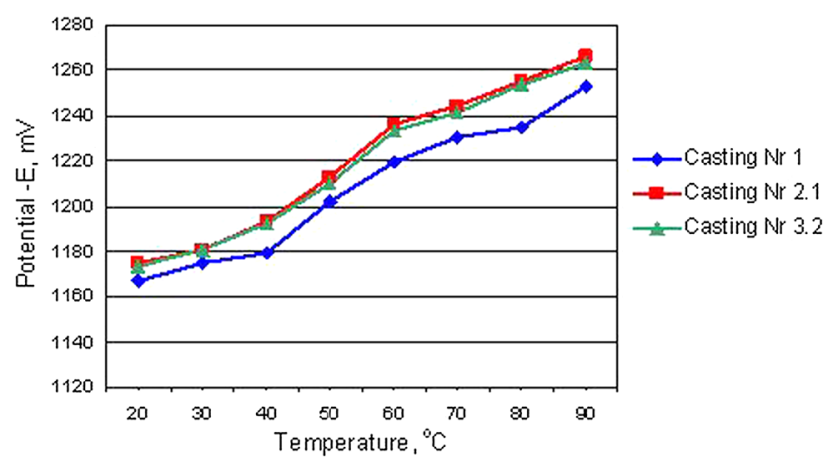

Figure 7. Increased potential during anodic polarization in dependence on the drink water temperature after 10-h testing.
After introducing $0.05 \% \mathrm{AlN}+\mathrm{Al}+\mathrm{Cu}$ and $0.1 \%$ $\mathrm{SiC}+\mathrm{Cu}$ in AlSi7Mg alloy, it could be seen:

- $\quad$ refining microstructure-DAS decreases with $26 \%$;

- decreasing porosity up to $70 \%$. The values are smaller than $0.5 \%$ and the requirements for casting density are satisfied;

- $\quad$ increasing yield strength with $7 \%$ and elongation up to $60 \%$;

- tensile strength changes less. More favorable is the influence of $0.1 \% \mathrm{SiC}+\mathrm{Cu}$ addition;

- $\quad$ effect of NP influence on the microstructure and properties after HT is less compared to this one before the HT;
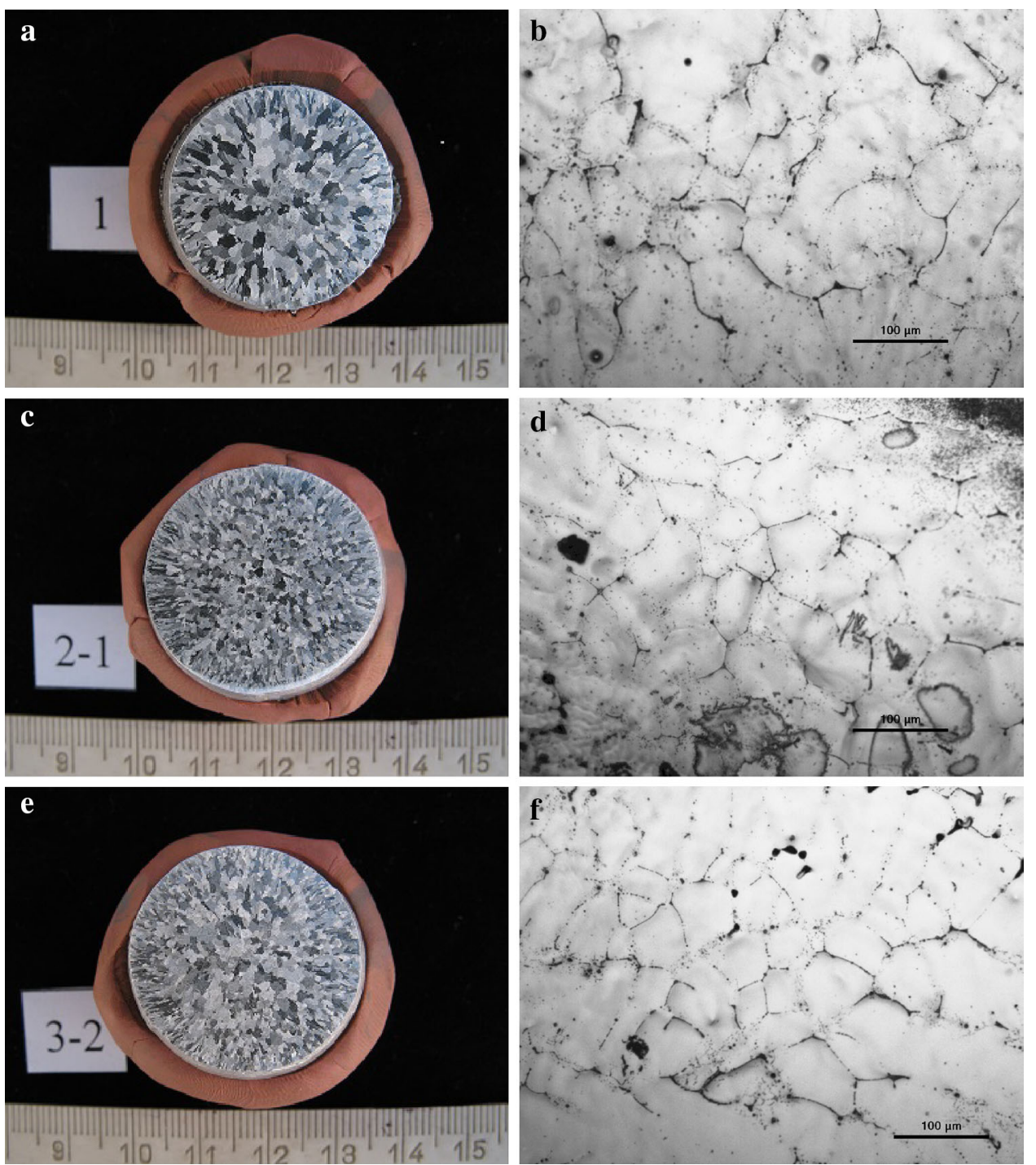

Figure 8. Macro- and microstructures of AIZn4 castings designed for protectors: (a) casting 1 without NP; (b) casting 2.1 refined with $0.05 \%$ AIN + Al (USD); and (c) casting 3.2 refined with $0.1 \%$ ND + Ag. 
- $\quad \mathrm{HB}>80$ in all zones of casting and meets the requirements;

- values of quality index $Q$ increase with 7-14\% and surpass $400 \mathrm{MPa}$. This is sufficient to assure $10^{7}$ cycles fatigue endurance at load 70-80 MPa, which is usually required for dynamic loaded parts and proves increased reliability of castings with NP addition.

All this means that nanopowder introducing in the melt of AlSi7Mg alloy leads to mechanical properties and total quality of castings improvement.

\section{AISi12Cu2MgNi Alloy}

The microstructure of this alloy consists also of dendrites of $\alpha$-solid solution, $\mathrm{Al}_{15}(\mathrm{FeMn})_{3} \mathrm{Si}_{2}$ phase-primary particles and eutectic of $\alpha$-solid solution, $\mathrm{Al}_{15}(\mathrm{FeMn})_{3} \mathrm{Si}_{2}$ phase particles and intermetallic compounds, ${ }^{22}$ as shown in Figure 6. The results from measuring microstructure parameters and mechanical testing the pistons before and after heat treatment are shown in Table 3.

NP addition leads to decreasing DAS up to $25 \%$. In cast state, $R_{m}$ increases with $3-6 \%$ and $A_{5}$ with $75 \%$. After HT, the increasing is less: $R_{m}$ is up to $4 \%$ and $A_{5}$ is up to $60 \%$. The hardness changes insignificantly. After HT, $\mathrm{HB}>150$ and fulfills the requirements. SiC $+\mathrm{AlN}$ has stronger influence than other investigated nanoparticles.

\section{AIZn4 Alloy}

\section{Investigation of Castings "Anode Protector" of AlZn4 Alloy with NP Addition}

The influence of nanosized AIN particles and nanodiamonds on the microstructure and electrochemical characteristics of "Anode protector" AlZn4 casting is investigated. It is designed for corrosion protection of enamel tank water heater and hulls of ships.

It is seen that the nanosized powders, AlN and ND $+\mathrm{Ag}$ added in AlZn4 alloy, influence on the electric potential of the protector alloy increasing the potential electronegativity as follows:

- The influence of both NP in drinking water after 1-h stabilization occurs up to $50{ }^{\circ} \mathrm{C}$ ( $E$ increases with 5-9\%). Then the values reach the values of initial alloy. Since we do not know other publications related to the electrochemical behavior of nanomodified alloys, the explanation for the changes above $60^{\circ}$ we could give after conducting further research in this direction;

- The protective potential E of alloys with NP addition after $10 \mathrm{~h}$ in drinking water is higher than the initial one in whole temperature range $\left(20-90{ }^{\circ} \mathrm{C}\right.$ ). Its increasing at $85{ }^{\circ} \mathrm{C}$ reaches $1.6 \%$;

- The protective potential $\mathrm{E}$ of all investigated alloys at $85^{\circ} \mathrm{C}$ is higher than the accepted by us minimal limitrophe potential $\left(E_{\min }=-980 \mathrm{mV}\right)$. It means that the cast anodes can serve as protectors.

The microstructure characteristics and density of AlZn4 castings designed for protectors are shown in Table 6.

Macro- and microstructures of AlZn4 castings designed for protectors are shown in Figure 8. It is visible that the structure is refined after NP addition. The values of mean diameter of the domains decrease with $37.2 \%$ and the mean grain diameter with $23 \%$ (Table 6).

The grains after NP addition are more rounded (1-ideal circle) that means more equal axed which is prerequisite for increasing protective potential. There is a tendency of raising density. The increase in density is also beneficial for the potential. The microhardness increases with $7 \%$. It could be concluded that the protective potential is structurally sensitive property.

\section{Conclusions}

1. After introducing NP in AlSi7Mg, it is established that microstructure is refined (DAS decreases with $26 \%$ ). Porosity is decreased (up to $70 \%$ ). The values are smaller than $0.5 \%$ so they satisfy the requirements for casting density. Yield strength is increased with $7 \%$ and specific elongation up to $60 \%$. Tensile strength changes less. Most favorable is the influence of $0.1 \% \mathrm{SiC}+\mathrm{Cu}$ addition. NP influence on microstructure and properties after HT is less compared to the one before HT. $\mathrm{HB}>80$ in all zones of casting and requirements are met. Values of quality index $Q$ increase (with $7-14 \%$ ) and surpass $400 \mathrm{MPa}$. This is sufficient for dynamic loaded parts.

2. NP addition leads to decreasing DAS (up to $25 \%$ ) in AlSi12Cu2MgNi alloy. In cast state, $R_{m}$ increases (with 3-6\%) and $A_{5}$ too (with $75 \%$ ). After heat treatment, the increasing is less $\left(R_{m}\right.$ raises up to $4 \%$ and $A_{5}$ up to $60 \%$ ). The hardness changes insignificantly. HB increases (over 150) and fulfills the requirements.

3. The influence of $\mathrm{NP}$ in $\mathrm{AlZn} 4$ alloy on its electrochemical characteristics as well as on the microstructure is established. There is a tendency towards an increasing of these characteristics. The increasing protection potential at $80-85^{\circ} \mathrm{C}$ in drinking water reaches $1.5-1.6 \%$. The microstructure is refined. The mean diameter of domains decreases (up to $51.5 \%$ ) and the mean grain diameter too (up to $23 \%$ ). After nanodiamond 
addition, the microhardness increases (up to $7 \%$ ). The density increases too.

4. The carried out investigation affirms the statement that the nanoparticles introduced in the melt of aluminum alloys act as centers of crystallization refining the microstructure. As a result, the microstructure susceptible mechanical end electrochemical properties are improved.

5. The mechanism of grain refining is discussed.

\section{Acknowledgments}

This work is financially supported by the Fund "Scientific Researches" at the Ministry of Education, Youth and Science, Project TK01/076.

Open Access This article is distributed under the terms of the Creative Commons Attribution 4.0 International License (http:// creativecommons.org/licenses/by/4.0/), which permits unrestricted use, distribution, and reproduction in any medium, provided you give appropriate credit to the original author(s) and the source, provide a link to the Creative Commons license, and indicate if changes were made.

\section{REFERENCES}

1. N.E. Kalinina., O.A. Kavatz, V.T. Kalinin, Technological properties improvement of cast aluminum alloys after modifying with nanodispersed particles. Airsp. Tech. Technol. 4(4), 17-21 (2010) (in Russian)

2. N.E. Kalinina et al., Nanomaterials and Nanotechnologies: Obtaining, Structure, Application (Publishing Hous U.V. Makovetskiy, Dnepropetrovsk, 2012)

3. R. Lazarova, R.H. Petrov, V. Gaydarova, A. Davidkov, A. Alexeev, M. Manchev, V. Manolov, Microstructure and mechanical properties of P265GH cast steel, after modification with TiCN particles. Mater. Des. 32, 2734-2741 (2011)

4. R. Lazarova, P. Kuzmanov, R. Dimitrova, A. Cherepanov, V. Manolov, Properties of 110Г13L. steel and SCh 25 cast iron modified by refractory nanopowder. Steel Transl. 42(4), 298-301 (2012)

5. P. Kuzmanov, R. Dimitrova, R. Lazarova, A. Cherepanov, S. Popov, R. Petrov, V. Manolov, Investigation of the structure and mechanical properties of castings of alloy AlSi7Mg, cast irons GG15 and GG25 and steel GX120Mn12, modified by nanosized powders. Proc. Inst. Mech. Eng., Part N: J. Nanoeng. Nanosyst. 228(1), 11-18 (2014)

6. M. Razavi, M.R. Rahimipour, A.H. Rajabi-Zamani, Effect of nanocrystalline TiC powder addition on the hardness and wear resistance of cast iron. Mater. Sci. Eng., A 454-455, 144-147 (2007)

7. R. Dimitrova, P. Kuzmanov, R. Lazarova, V. Manolov, Investigation of nanopowders application in metal casting. Adv. Mater. Res. 629, 284-291 (2013)
8. K. Borodianskiy, M. Zinigrad, A. Gedanken, Aluminum A356 reinforcement by carbide nanoparticles. J. Nano Res. 13, 41-46 (2011)

9. R. Dimitrova, S. Stanev, A. Velikov, A. Cherepanov, R. Lazarova, N. Bojanova, Investigation of AlSi7Mg casting refined with $\mathrm{SiC}$ nano-powder. J. Mater. Sci. Technol. 20(4), 319-326 (2012)

10. K. Borodianskiy, A. Kossenko, M. Zinigrad, Improvement of the mechanical properties of $\mathrm{Al}-\mathrm{Si}$ alloys by TiC nanoparticles. Metall. Mater. Trans. A 44(11), 4948-4953 (2013)

11. M. Habibnejad-Korayem, R. Mahmudi, W.J. Poole, Enhanced properties of $\mathrm{Mg}$ based nano-composites reinforced with $\mathrm{Al}_{2} \mathrm{O}_{3}$ nano-particles. Mater. Sci. Eng., A 519, 198-203 (2009)

12. M. Habibnejad-Korayem, R. Mahmudi, H.M. Ghasemi, W.J. Poole, Tribological behavior of pure $\mathrm{Mg}$ and $\mathrm{AZ31}$ magnesium alloy strengthened by $\mathrm{Al}_{2} \mathrm{O}_{3}$ nanoparticles. Wear 268, 405-412 (2010)

13. Y. Hou, Y. Wang, Z. Pan, L. Yu, Influence of rare earth nanoparticles and inoculants on performance and microstructure of high chromium cast iron. J. Rare Earths 30(3), 283-288 (2012)

14. S. Stavrev, Z. Karaguiozova, Formation of Nickel Layer-Covers on Nanodiamond Powder, Nanoscience \& Nanotechnology, 7 (Heron Press, Sofia, 2007), pp. 219-221

15. V. Kovachev, I. Panov, Investigation of the possibility for electrical and chemical characteristics improvement of aluminum protectors. Scientific Announcements of NTUM VI (17), pp. 85-106. ISSN 1310-3946 (1998)

16. G.G. Krushenko, S.N. Reshetnikova, A.A. Mishin, The mechanism of aluminium-silicon alloys inoculation by nanopowders (at nanopowder of titanium nitride example), in Proceedings from XIV International Scientific Conference "Reshetnev Readings", Krasnoyarsk, 10-12.11.2010, Part 2, pp. 586-587 (in Russian)

17. A. Einstein, M. Smoluchowski, Brownian Motion. Translated by K. I. Fedchenko, ed. by B. I. Davidov (ONTI Home Edition of General Technical Literature, 1936), p. 607 (in Russian)

18. P.D. Dankov, Crystal-chemical mechanism of crystal surface interaction with alien elementary particles. J. Phys. Chem. 20(8), 853-867 (1946). (in Russian)

19. S. Stanev, R. Lazarova, S. Konstantinova, V. Manolov, Investigation of the effect from AlS7Mg alloy modification with nanopowders by thermal and metallographic analyses, in Proceedings from XXVI International Scientific Conference 65 Years Faculty of Machine Technology, 13-16 September 2010, Sozopol, Bulgaria, pp. 277-282

20. S.N. Reshetnikova, Ph.D. thesis, http://www. dissercat.com/content/primenenie-nanoporo shkov-khimicheskikh-soedinenii-dlya-povyshe niya-fiziko-mekhanicheskikh-kh (in Russian) 
21. M. Drouzy, S. Jacob, M. Richard, Interpretation of tensile results by means of quality index and probable yield strength. AFS Int. Cast Met. J. 45, 43-50 (1980)

22. M.E. Samoshina, N.A. Belov, S.V. Savchenko, The features of phase composition and microstructure of piston alloys AlSi12CuMgNi and AlSi12Cu2MgNi. Non-ferr. Met. (9) (2012). http://www.rudmet.ru/ journal/946/article/14803/ 